\title{
Diagnosis of Bloom Syndrome in a Patient with Short Stature, Recurrence of Malignant Lymphoma, and Consanguineous Origin
}

\author{
Jakub Trizuljak ${ }^{a-c}$ Terezie Petruchováa Ivona Blahákováb,c \\ Zuzana Vrzalováb, c Věra Hořínovád Martina Doubkováe Jozef Michalkaa,b \\ Jiří Mayera-c Šárka Pospíšilováa-c Michael Doubek ${ }^{a-c}$ \\ ${ }^{a}$ Faculty of Medicine, Masaryk University, Brno, Czech Republic; ${ }^{\text {b }}$ Department of Internal Medicine, Hematology \\ and Oncology, University Hospital Brno, Brno, Czech Republic; ${ }^{C}$ Central European Institute of Technology, \\ Masaryk University, Brno, Czech Republic; ${ }^{d}$ Outpatient Ward for Genetics, Hospital Jihlava, Jihlava, Czech Republic; \\ e Department of Pulmonary Diseases and Tuberculosis, University Hospital, Brno, Czech Republic
}

\section{Keywords}

Autosomal recessive variant $\cdot B L M \cdot$ Bloom syndrome .

Consanguinity $\cdot$ Lymphoma

\section{Abstract}

Bloom syndrome is an autosomal recessive disorder characterized by prenatal and postnatal growth deficiency, photosensitive skin changes, immune deficiency, insulin resistance, and a greatly increased risk of early-onset cancer and development of multiple malignancies. Loss-of-function variants of the BLM gene, which codes for a RecQ helicase, cause Bloom syndrome. We report a consanguineous family, with 2 siblings showing clinical signs of suspected chromosome breakage disorder. One of them developed recurrent malignant lymphoma during lifetime. We performed next-generation sequencing analysis, focusing on cancer predisposition syndromes. We identified a homozygous pathogenic nonsense variant c.1642C>T (p.GIn548*) in the $B L M$ gene in the proband, associated with Bloom syndrome. Sanger sequencing validated the presence of a homozygous pathogenic variant in the proband and also in the brother with short stature. In this article, we will focus on the

\section{KARGER}

karger@karger.com www.karger.com/msy
(C) 2020 TheAuthor(s)

Published by S. Karger AG, Basel

Karger

Open access

This article is licensed under the Creative Commons AttributionNonCommercial-NoDerivatives 4.0 International License (CC BYNC-ND) (http://www.karger.com/Services/OpenAccessLicense). Usage and distribution for commercial purposes as well as any distribution of modified material requires written permission. clinical presentation of the syndrome in this particular family as well as the characteristics of malignancies found in the proband.

(C) 2020 The Author(s)

Published by S. Karger AG, Basel

Bloom syndrome is an autosomal recessive disorder characterized by prenatal and postnatal growth deficiency, photosensitive skin changes, immune deficiency, insulin resistance, pulmonary involvement, and cancer predisposition [German, 1969; Gretzula et al., 1987; Diaz et al., 2006; McGowan et al., 2009; Nair et al., 2009; Masmoudi et al., 2012; Arora et al., 2014; Relhan et al., 2015]. Bloom syndrome is caused by loss-of-function variants in the BLM gene. The absence of a functional BLM protein causes chromosome instability, excessive homologous recombination, and a greatly increased number of sister chromatid exchanges that are typical for the syndrome [Ellis et al., 1995; Karow et al., 1997]. Bloom syndrome is an extremely rare disease. The estimated carrier frequency is $1 / 500$ in the Czech population and 1/120 in the Ashkenazi Jewish population [Shahrabani-Gargir et al., 1998; 


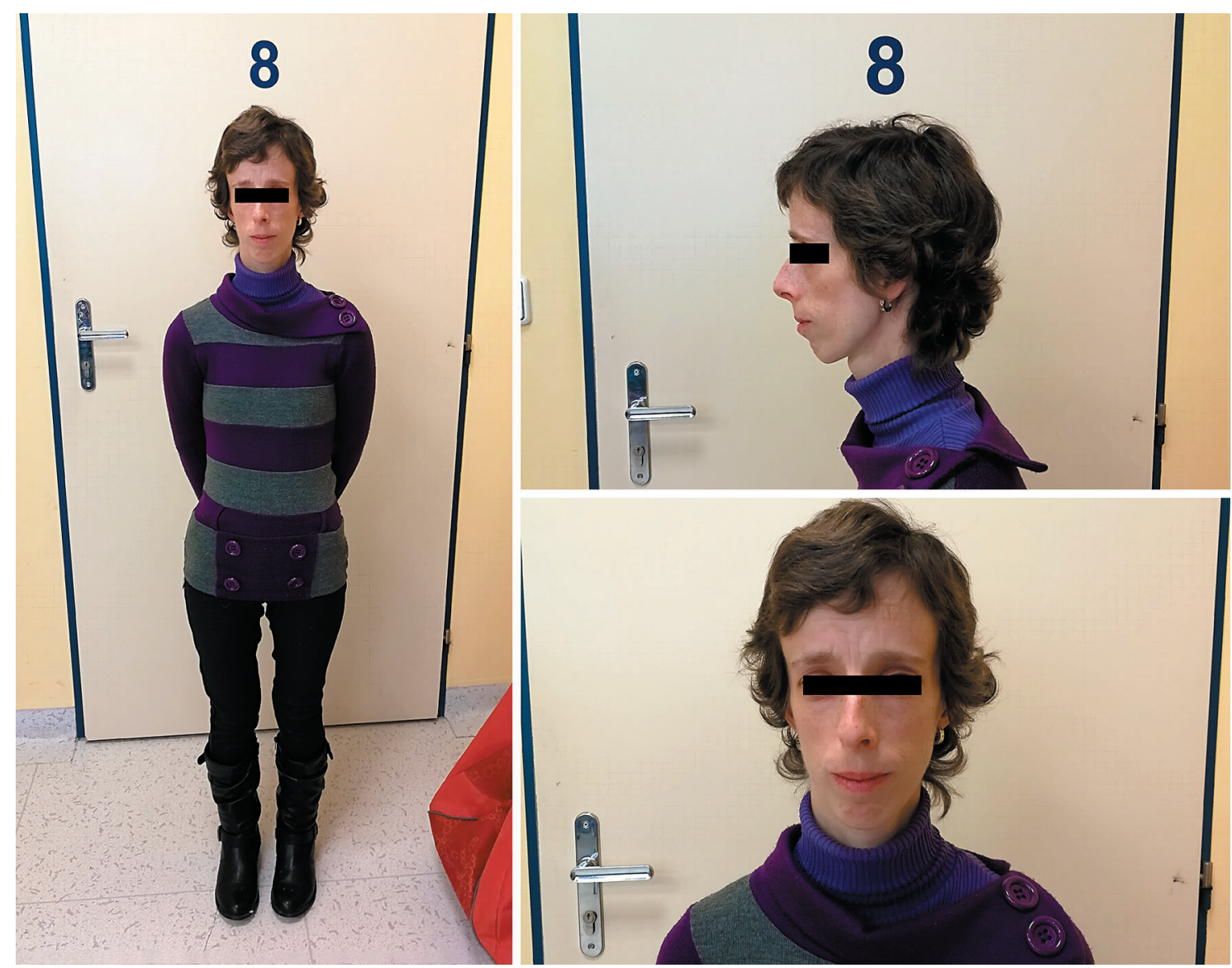

Fig. 1. Picture of the proband with short stature and facial dysmorphism. Note the narrow, prolonged face, protruding nose, and retrognathia.

Seemanová et al., 2002]. Recurrent founder mutations are present in individuals with Bloom syndrome, notably the $B L M^{\text {Ash }}$ mutation [German et al., 2007; Kaseb and Hozayen, 2019] and c.1642C $>\mathrm{T}$ in the Slavic population [Sokolenko et al., 2012; Prokofyeva et al., 2013]. Bloom syndrome has an estimated risk of malignancy around 4050\% [Foretová and Petráková, 2019]. There is a wide variety of cancer types and anatomic sites in patients with Bloom syndrome. Cancer typically occurs at a younger age and might be recurrent. Hematologic malignancies (acute myeloid leukemia, acute lymphoblastic leukemia, and lymphoma) are the most common malignancies in individuals with Bloom syndrome. Among solid tumors, digestive tract cancers are the most common, particularly adenocarcinoma of the upper and lower intestinal tract. Squamous cell carcinomas of the head and neck as well as breast cancer have also been frequently reported. In addition to common malignancies, persons with Bloom syndrome have an excess of rare cancers, particularly Wilms tumor [Cairney et al., 1987; Berger et al., 1996]. Although there is currently no treatment for the underlying genetic abnormality, persons with Bloom syndrome benefit from sun protection, aggressive treatment of infections, surveillance for endocrinopathies, and early identification of cancer [Cunniff et al., 2017; Flanagan and Cunniff, 2019].

\section{Case Report}

\section{Personal History}

We report a female patient with short stature and facial dysmorphism (Fig. 1). She had a medical history of failure to thrive, dermatological symptoms (café-au-lait spots, keratosis pilaris, and onychodystrophy), hypothyreosis, premature ovarian failure, persistent bronchial asthma, bronchiectasis, and recurring episodes of pneumonia during her childhood and adolescence.

\section{Manifestation of First Malignancy}

At the age of 15, the patient was diagnosed with non-Hodgkin lymphoma. Few data are available due to the patient's treatment in 


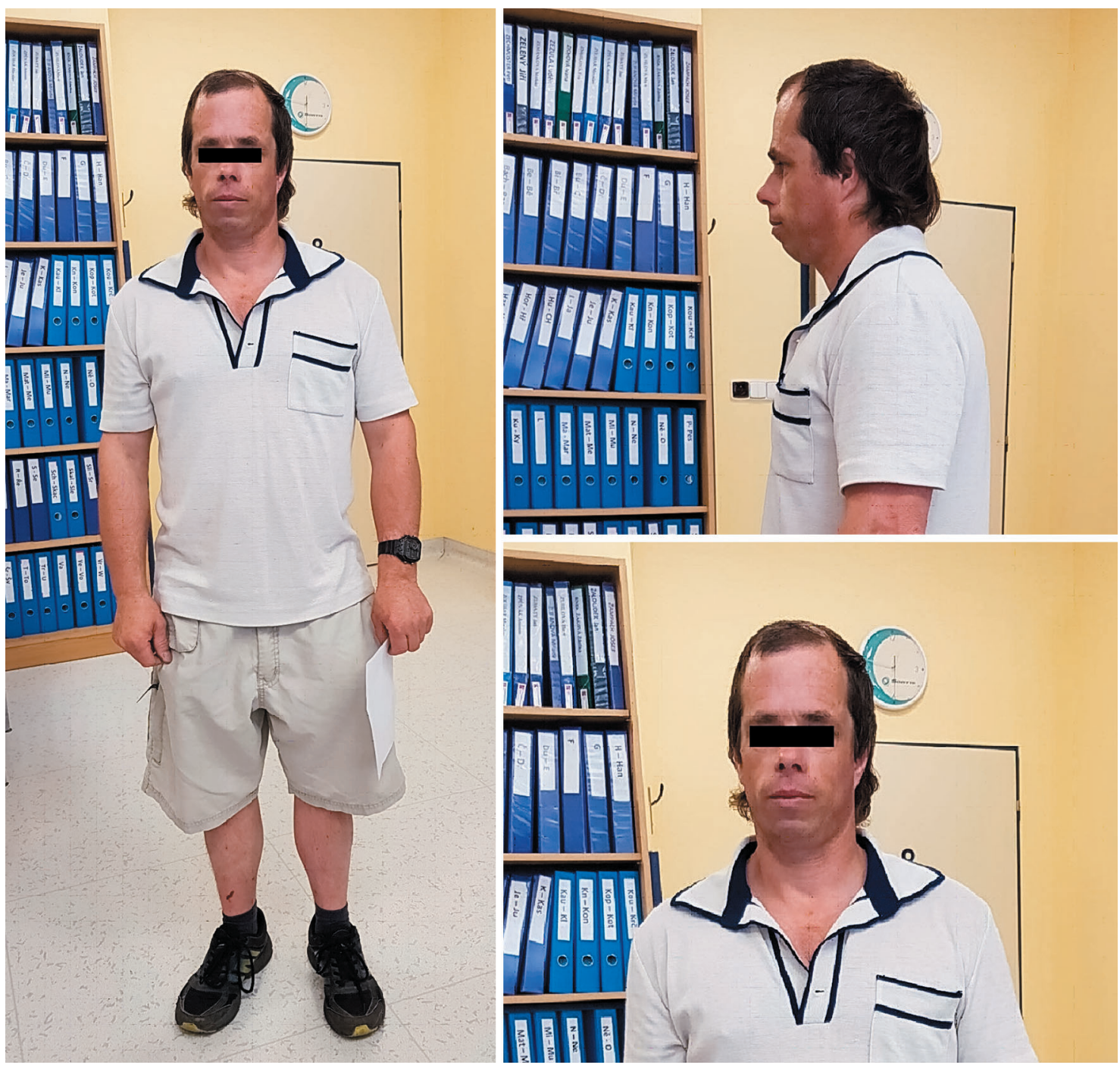

Fig. 2. Picture of the sibling with short stature and facial dysmorphism. Note the prolonged face, abnormal chin, and high forehead.

the year 1998. The disease was classified as centroblastic B-cell non-Hodgkin lymphoma of the neck and nasopharynx. The treatment was administered per NHL-BFM 95 protocol and consisted of vincristine, etoposide, cytarabine, methotrexate, ifosfamide, cyclophosphamide, prednisolone, and doxorubicin with concomitant intrathecal applications of chemotherapy. The final assessment confirmed complete remission.

\section{Manifestation of Second Malignancy}

In December 2017, the proband was admitted to the surgical department because of abdominal pain, intussusception, and suspicion of tumor in the cecum per imaging procedures. She complained about 2-3 months of nonspecific gastrointestinal problems, cramps, obstipation, and $2 \mathrm{~kg}$ weight loss. Her actual weight was only $29 \mathrm{~kg}$, height was $140 \mathrm{~cm}$, and BMI was $14.8 \mathrm{~kg} /$ $\mathrm{m}^{2}$ per duBois formula. The patient also referred to previous sus- picion of celiac disease. Laparotomic hemicolectomy with terminal ileostomy was performed, and a $45-\mathrm{mm}$ tumor in the cecum was removed together with 12 regional mesenteric lymph nodes. Histopathological evaluation of the involved tissues (tumor, bowel, mesenteric lymph nodes) was performed by the experienced pathologist with the conclusion of high-grade B-lymphoma, not otherwise specified, possibly Burkitt-like lymphoma with $11 \mathrm{q}$ aberration. The clinical stage was II AE per Ann Arbor classification, aaIPI 1 (LDH level 4.59 slightly above normal range). Microscopically, the tumor consisted of medium-sized immunoblasts and centroblasts with high mitotic activity, Ki67 80-100\%. Immunophenotyping of malignant cells showed positivity on CD20, CD10, bcl-6, MUM-1 and MYC, and negativity on CD3, bcl-2, CD5, cyclin D1 and CD30. Due to her poor nutritional status, radical surgical resection of the involved tissues, low-risk aaIPI, and a lack of therapeutic guidelines in such cases, we ad- 


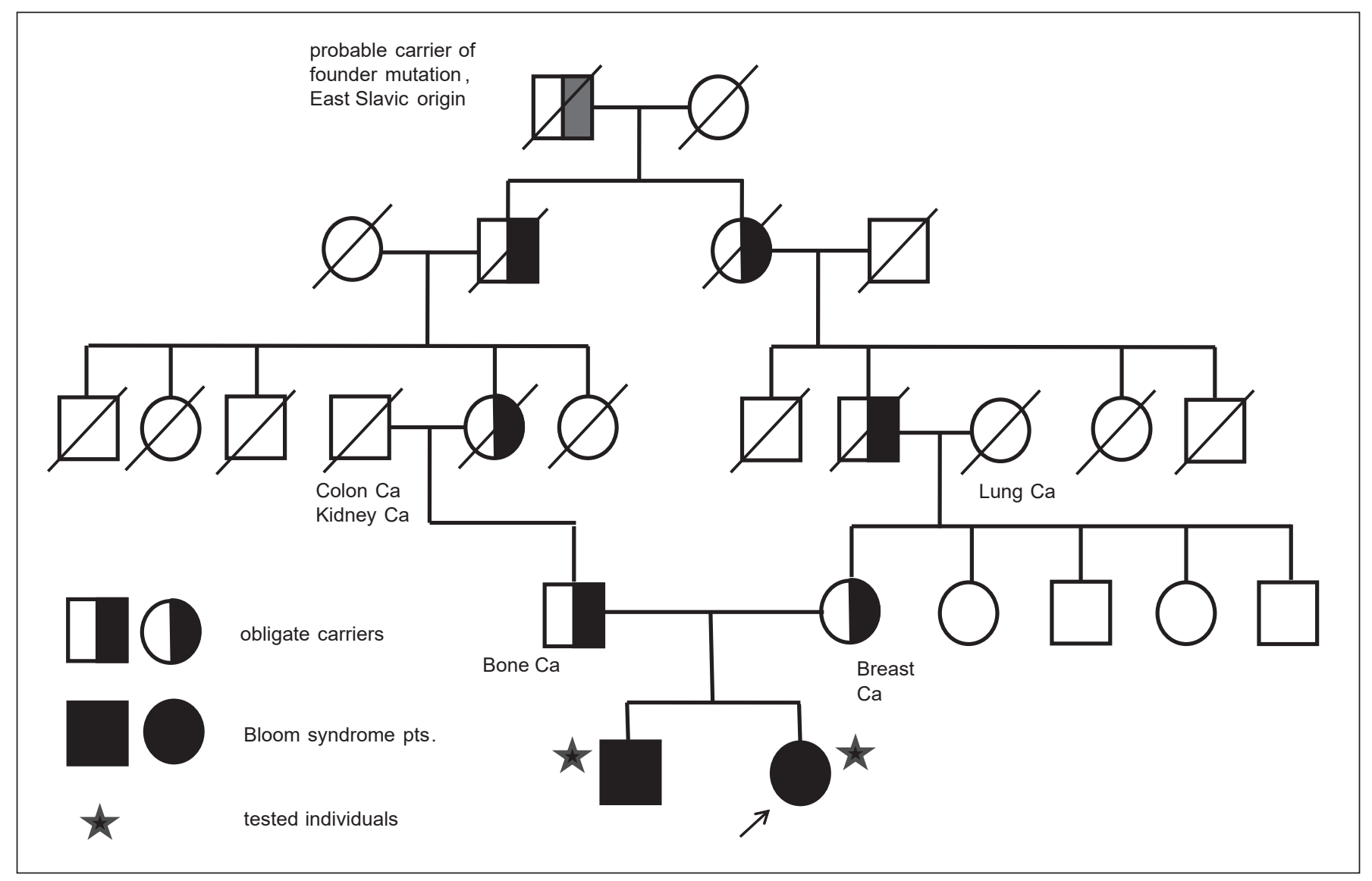

Fig. 3. Pedigree of the consanguineous family with Bloom syndrome showing the obligate carriers and the potential founding mutation carrier.

ministered "standard" combined chemotherapy regimen consisting of 6 R-CHOP (rituximab, cyclophosphamide, doxorubicin, vincristine, and prednisone) cycles with respect to cumulative doses of anthracyclines used before and initial omission of vincristine. One more single agent rituximab was administered in May 2018. The whole treatment was not accompanied by significant adverse events, and the final restaging PET/CT scan was evaluated as complete remission of the lymphoma. In June 2018, terminal ileostomy was canceled. So far, the patient remains in complete remission more than one year after treatment completion. The main ongoing problem is severe malnutrition, weight $27.5 \mathrm{~kg}$ and BMI $14.0 \mathrm{~kg} / \mathrm{m}^{2}$.

\section{Family History}

The brother of the proband also displayed short stature and facial dysmorphism (Fig. 2). He was diagnosed with growth restriction, pubertas praecox, retention of testes, and teleangiectasias on sun-exposed areas. There was no history of cancer or other difficulties. The parents of the siblings were consanguineous, with a potential carrier of the founder mutation, originating from the east Ukraine/Russian region (Fig. 3). There was a sporadic occurrence of solid cancer in the pedigree, not segregating with obligate carriers.

\section{Methods and Results}

\section{Mutational Screening and Confirmation}

A homozygous pathogenic variant c.1642C>T (p.Gln548*) in the BLM gene (NM_000057.3) was detected in the proband (Fig. 4). This variant results in a premature termination codon predicted to cause a truncated or absent BLM protein due to nonsense-mediated decay. The variant is classified as pathogenic - class 5, according to ACMG/AMP standards and guidelines [Richards et al., 2015; Kleinberger et al., 2016]. The presence of the pathogenic variant was confirmed by Sanger sequencing (Fig. 5).

Predictive testing was performed in the male sibling. Testing by Sanger sequencing confirmed the presence of a homozygous c. $1642 \mathrm{C}>\mathrm{T}$ pathogenic variant in the $B L M$ gene.

\section{Cytogenetic Studies}

Samples from the proband and her brother were studied by conventional karyotyping, followed by chromosome breakage analysis. Cytogenetic study determined a normal female karyotype $(46, \mathrm{XX})$ in the proband and a normal male karyotype $(46, \mathrm{XY})$ in her brother. Acquired chromosomal aberrations were present in $27 \%$ of all metaphase nuclei in the proband, and in $7 \%$ in her brother, respectively (Fig. 6, 7). 


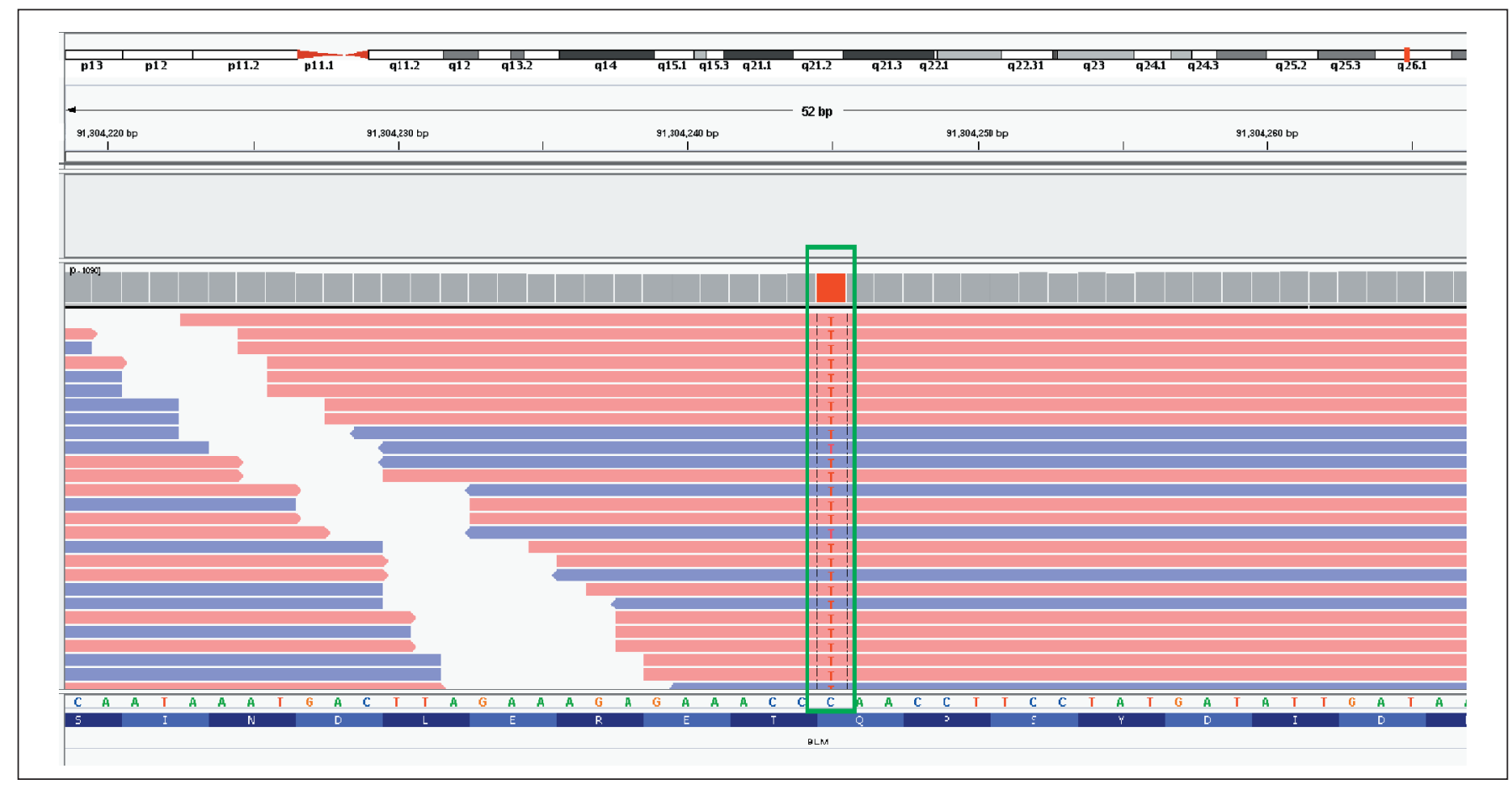

Fig. 4. Analysis of the c.1642C > T pathogenic variant (g.100183535C >T) by Integrative Genomics Viewer (green box). Forward sequencing reads are in blue; reverse sequencing reads are in pink.

\section{Discussion}

In this report, we describe a 35-year-old woman with Bloom syndrome. She presented with short stature, facial dysmorphism, premature ovarian failure, endocrine abnormalities, lung involvement, and recurrent malignant lymphoma at 15 and 34 years. At the time of the second oncological diagnosis, we considered other chromosome instability syndromes, notably Nijmegen breakage syndrome, Werner syndrome, and ataxia teleangiectasia. Other RecQ-related disorders: Rothmund Thomson, RAPADILINO, and Baller Gerold syndrome, associated with RECQL4 pathogenic variants, and disorders caused by pathogenic variants in RMI1, RMI2, and TOP3A helicase genes (OMIM 610404, 612426, and 618097) were also considered (for phenotypic comparison, and see Table 1).

According to medical records, in the year 2000, the proband tested negative for the c.657del 5 NBN pathogenic variant, and positive for chromosomal instability. Definitive diagnosis of Bloom syndrome was confirmed only after the identification of a homozygous c.1642C>T pathogenic variant in the BLM gene. These results were consistent with consanguineous origin, identifying a probable founder from Slavic East-Europe in the pedigree.

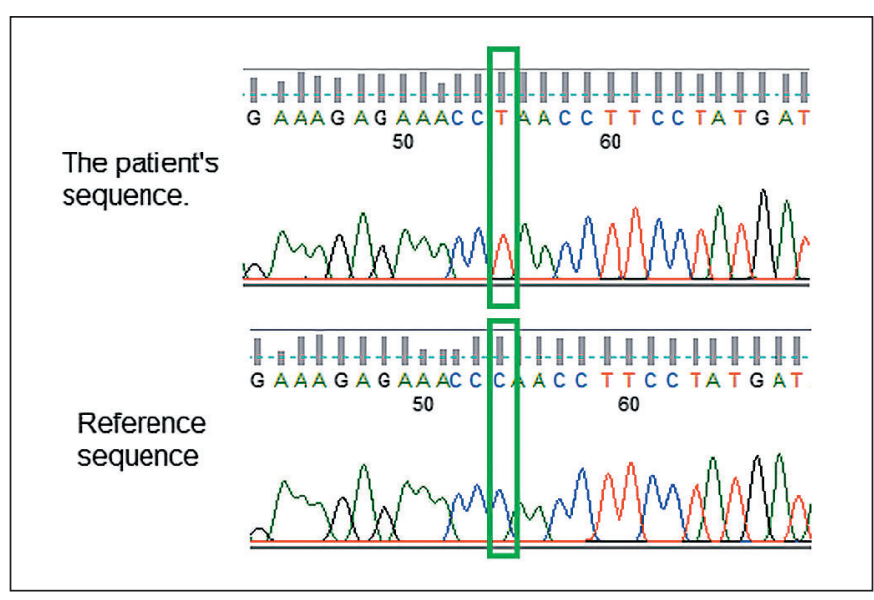

Fig. 5. Sanger sequencing results of homozygous c.1642C>T pathogenic variant compared with wild type.

The treatment with immunochemotherapy was started without prior knowledge of NGS results. Therefore, it was tailored more to the clinical and nutritional state of the patient than genetics. Standard combined chemotherapy regimen with curative intent was used, consisting of $6 \mathrm{R}-\mathrm{CHOP}$ cycles with initial omission of vincristine. 
Fig. 6. Metaphase nuclei of the proband showing acquired chromosomal aberrations.

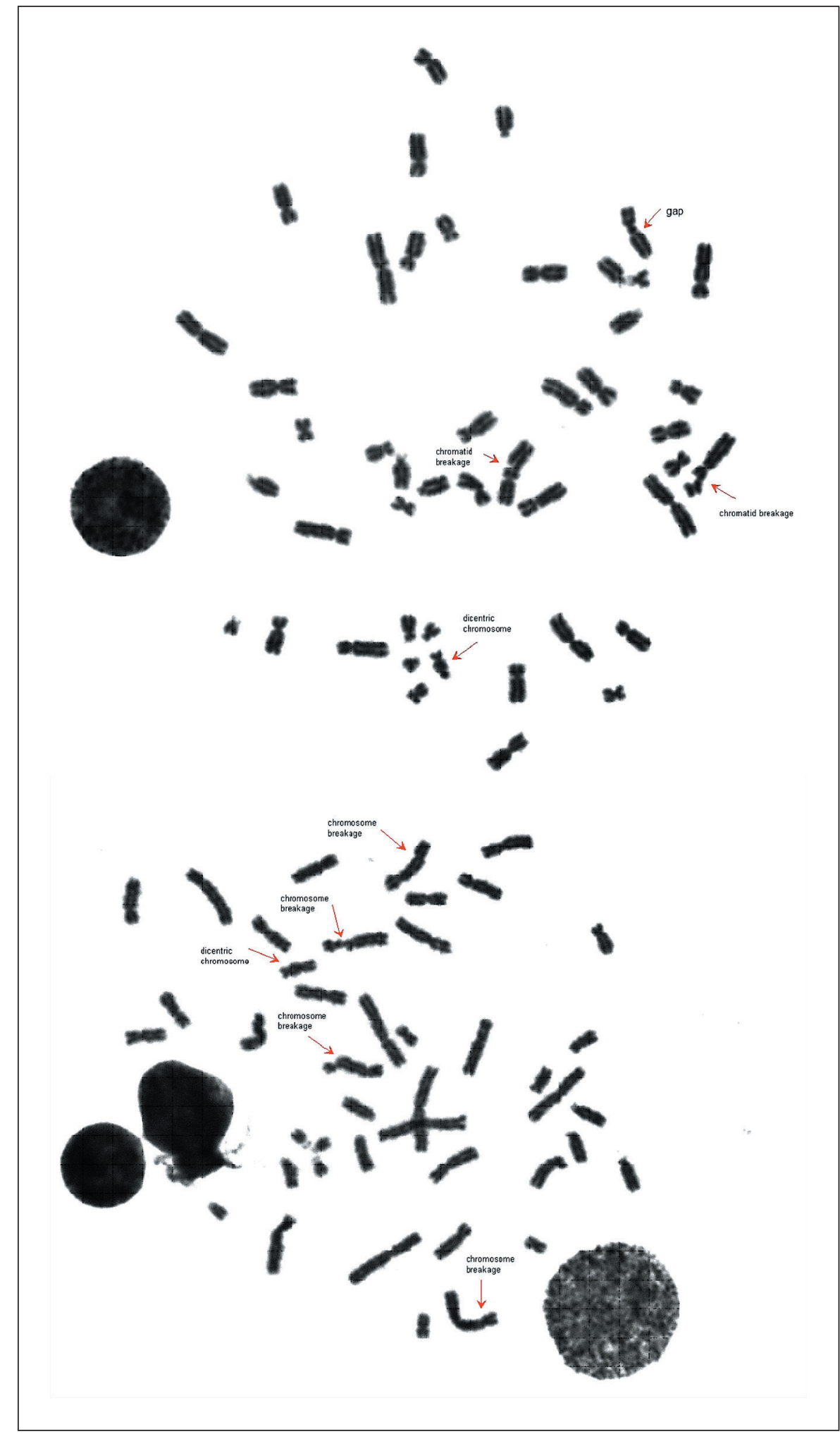


Fig. 7. Metaphase nuclei of the sibling showing acquired chromosomal aberrations. Frequency of breakages is much lower than in the proband.

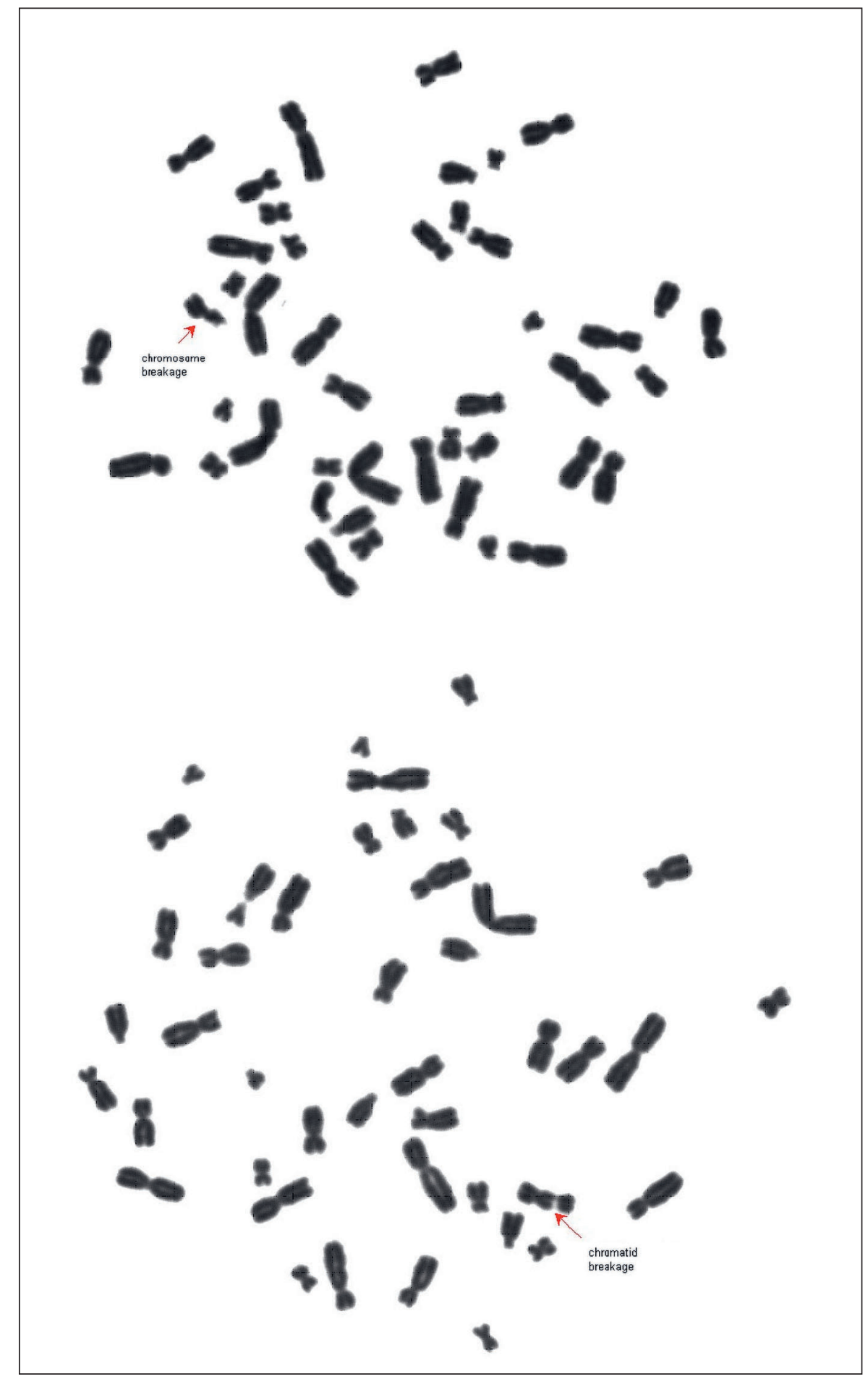

The patient experienced no major complications, such as cytopenias or life-threating infections. In hindsight, a nonintensive regimen was definitely optimal. With prior knowledge of Bloom syndrome diagnosis, an even more moderate treatment, such as Nijmegen protocol with $20 \%$ dose reduction [Dembowska-Baginska et al., 2009], could have been used. In the recent reviews, dose reduction up to $50 \%$ is recommended [Cunnif et al., 2018]. Some authors report more dramatic toxicity of treatment [Fedhila-Ben Ayed et al., 2016], while others report successful 
Table 1. Comparison of clinical findings in chromosome breakage disorders and helicase disorders

\begin{tabular}{|c|c|c|c|c|c|c|c|c|}
\hline Clinical features & $\begin{array}{l}\text { Nijmegen breakage } \\
\text { syndrome }\end{array}$ & Werner syndrome & Bloom syndrome & $\begin{array}{l}\text { Ataxia teleangiec- } \\
\text { tasia }\end{array}$ & Beller-Gerold & Rotmund-Thompson & RAPADILINO & $\begin{array}{l}\text { Helicase } \\
\text { disorders: } \\
\text { RMI1, } \\
\text { RMI2, } \\
\text { TOP3A }\end{array}$ \\
\hline IUG & + & + & + & $+/-$ & + & $+/-$ & + & + \\
\hline Short stature & + & + & + & $+1-$ & + & $+1-$ & + & + \\
\hline Microcephaly & + & + & + & $+1-$ & + & + & + & + \\
\hline $\begin{array}{l}\text { Facial dysmor- } \\
\text { phism }\end{array}$ & $\begin{array}{l}\text { Receding mandibula, } \\
\text { bird-like face }\end{array}$ & + & $\begin{array}{l}\text { Long and narrow face, } \\
\text { retrognathia, microgna- } \\
\text { thia }\end{array}$ & $+1-$ & $\begin{array}{l}\text { Oxycephaly, } \\
\text { turicephaly }\end{array}$ & Craniosynostosis & + & $+1-$ \\
\hline $\begin{array}{l}\text { Skeletal abnorma- } \\
\text { lities }\end{array}$ & - & - & - & - & $\begin{array}{l}\text { Radial aplasia, } \\
\text { ulnar hypoplasia }\end{array}$ & $\begin{array}{l}\text { Frontal bossing, } \\
\text { saddle nose, radial } \\
\text { ray defects }\end{array}$ & $\begin{array}{l}\text { Radial and } \\
\text { patellar aplasia }\end{array}$ & - \\
\hline $\begin{array}{l}\text { Skin manifesta- } \\
\text { tions }\end{array}$ & $\begin{array}{l}\text { Café-au-lait patches, } \\
\text { teleangiectasia }\end{array}$ & Scleroderma, cataract & $\begin{array}{l}\text { Café-au-lait patches, } \\
\text { malar rash }\end{array}$ & Teleangiectasia & Poikiloderma & $\begin{array}{l}\text { Pigmentation, } \\
\text { teleangiectasia, } \\
\text { poikiloderma }\end{array}$ & - & $\begin{array}{l}\text { Café-au-lait } \\
\text { patches }\end{array}$ \\
\hline $\begin{array}{l}\text { Intellectual disabi- } \\
\text { lity }\end{array}$ & -Normal/mild & - & - & - & $+/-$ & - & - & Mild \\
\hline $\begin{array}{l}\text { Cardiac malfor- } \\
\text { mations }\end{array}$ & - & - & - & - & $+/-$ & - & - & + \\
\hline $\begin{array}{l}\text { Endocrine dys- } \\
\text { function }\end{array}$ & + & $\begin{array}{l}\text { Premature diabetes } \\
\text { mellitus }\end{array}$ & $\begin{array}{l}\text { Premature diabetes, } \\
\text { hypothyreoidism }\end{array}$ & - & - & - & - & - \\
\hline $\begin{array}{l}\text { Pulmonary mani- } \\
\text { festations }\end{array}$ & Bronchiectasia & - & $\begin{array}{l}\text { Pulmonary fibrosis, } \\
\text { bronchiectasia }\end{array}$ & Bronchiectasia & - & - & - & - \\
\hline $\begin{array}{l}\text { GIT manifesta- } \\
\text { tions }\end{array}$ & - & - & - & - & $\begin{array}{l}\text { Anogenital } \\
\text { malformations }\end{array}$ & $\begin{array}{l}\text { Anorectal } \\
\text { malformations, } \\
\text { pylorostenosis }\end{array}$ & $\begin{array}{l}\text { Persistent } \\
\text { diarrhea }\end{array}$ & GE reflux \\
\hline $\begin{array}{l}\text { Neurological } \\
\text { manifestations }\end{array}$ & - & - & - & $\begin{array}{l}\text { Ataxia, progressive } \\
\text { degeneration }\end{array}$ & & - & - & - \\
\hline Infertility & + & + & + & + & - & + & - & Unknown \\
\hline $\begin{array}{l}\text { Immune defici- } \\
\text { ency }\end{array}$ & + & + & + & + & - & $+/-$ & - & + \\
\hline $\begin{array}{l}\text { Increased risk of } \\
\text { malignancy }\end{array}$ & $\begin{array}{l}\text { Lymphomas, } \\
\text { leukemias, CNS } \\
\text { tumors }\end{array}$ & + & $\begin{array}{l}\text { Lymphomas, leukemias, } \\
\text { solid cancers }\end{array}$ & $\begin{array}{l}\text { Leukemias, breast } \\
\text { cancer }\end{array}$ & Unknown & $\begin{array}{l}\text { Osteosarcoma, skin } \\
\text { cancer }\end{array}$ & Unknown & Unknown \\
\hline $\begin{array}{l}\text { Chromosome } \\
\text { instability }\end{array}$ & + & + & + & + & - & - & - & + \\
\hline
\end{tabular}

CNS, central nervous system; GE, gastroesophageal; GIT, gastrointestinal tract; IUG, intrauterine growth restriction

treatment with similar regimens [Jastaniah, 2017]. Despite generally high treatment response rates in some of the aggressive B-cell lymphomas, relapses can occur, mostly in the first $2-3$ years after treatment completion. In the case report as described above, there is not only a high risk of another relapse, but also of secondary malignancies.

Classifications of lymphoid malignancies developed dramatically during the last decades, reflecting morphology, immunophenotype, clinical presentation, cytogenetics, and molecular genetics. During the manifestation of the first malignancy in the 1990s, REAL (Revised European-American Lymphoma) classification was used. The tumor was classified as centroblastic B-
NHL. During the manifestation of the second malignancy in 2017, revised WHO classification was used [Swerdlow et al., 2016]. The patient's lymphoma was classified as high-grade B-lymphoma, not otherwise specified, possibly Burkitt-like lymphoma with $11 \mathrm{q}$ aberration. We cannot rule out the possibility of a late relapse because the tumors share some features (presence of centroblasts, sudden onset and aggresivity). However, due to different anatomical locations of onset, we suggest that an entirely new lymphoproliferative disease might have occurred. This could be confirmed only using genome profile expression techniques. Unfortunately, no histological sample was available from the time of first diagnosis. 
Table 2. Comparison of clinical findings in the female proband and her brother

\begin{tabular}{|c|c|c|}
\hline Clinical findings & Proband & Brother \\
\hline Short stature & Yes & Yes \\
\hline Microcephaly & Yes & Yes \\
\hline Facial dysmorphism & Prolonged face, micrognathia, retrognathia, gothic plate, prominent features & Prolonged face, retrognathia \\
\hline Skin manifestations & Keratosis plaris, café-au-lait spots & Teleangiectasia \\
\hline Intellectual disability & No & No \\
\hline Endocrine dysfunction & Yes & No \\
\hline Pulmonary manifestations & Pulmonary fibrosis, asthma, bronchiectasia & No \\
\hline Infertility & Primary amenorrhea & Yes \\
\hline Immune deficiency & Yes & Unknown \\
\hline Malignancies & Duplicity of malignant lymphoma & No \\
\hline Chromosome instability & $29 \%$ aberrant nuclei & $7 \%$ aberrant nuclei \\
\hline
\end{tabular}

Our case also demonstrates individual variability in patients with Bloom syndrome, even within a single family. While the proband developed recurrent malignant lymphoma and suffered from multiple endocrine dysfunctions as well as severe underweight, the brother had no major health conditions, apart from increased sensitivity to sun (Table 2). Interestingly, there were significant differences in the rate of spontaneous chromosomal aberrations between the siblings. This could be partially attributed to the genotoxic treatment undergone by the proband. However, more factors (functionality of other gene-repair mechanisms, immune surveillance for cancer) could have caused this difference.

\section{Conclusions}

We present a sibling pair with Bloom syndrome with consanguineous origin and recurrence of lymphoid malignancies in the proband. These are among the first reported cases of Bloom syndrome in the Czech Republic.
Early diagnosis of similar disorders may lead to early cancer detection and prevention, correct dosage of cytostatic regimens, improved clinical outcomes, and improved life expectancy of affected individuals.

\section{Statement of Ethics}

The authors have no ethical conflicts to disclose.

\section{Disclosure Statement}

The authors have no conflicts of interest to declare.

\section{Funding Sources}

This study was supported by the Czech Ministry of Health (grant AZV NU20-08-00137 16-29447A) and the Masaryk University (grant MUNI/A/1395/2019).

\section{References}

Arora H, Chacon AH, Choudhary S, McLeod MP, Meshkov L, et al: Bloom syndrome. Int J Dermatol 53: 798-802 (2014).

Berger C, Frappaz D, Leroux D, Blez F, Vercherat $\mathrm{M}$, et al: Wilms tumor and Bloom syndrome (in French). Arch Pediatr 3:802-805 (1996).

Cairney AE, Andrews M, Greenberg M, Smith D, Weksberg R: Wilms tumor in three patients with Bloom syndrome. J Pediatr 111:414-416 (1987).

Cunniff C, Bassetti JA, Ellis NA: Bloom's syndrome: clinical spectrum, molecular pathogenesis, and cancer predisposition. Mol Syndromol 8:4-23 (2017).
Cunniff C, Djavid AR, Carrubba S, Cohen B, Ellis NA, et al: Health supervision for people with Bloom syndrome. Am J Med Genet A 176: 1872-1881 (2018)

Dembowska-Baginska B, Perek D, Brozyna A, Wakulinska A, Olczak-Kowalczyk D, et al: Non-Hodgkin lymphoma (NHL) in children with Nijmegen Breakage syndrome (NBS). Pediatr Blood Cancer 52:186-190 (2009).

Diaz A, Vogiatzi MG, Sanz MM, German J: Evaluation of short stature, carbohydrate metabolism and other endocrinopathies in Bloom's syndrome. Horm Res 66:111-117 (2006).
Ellis NA, Groden J, Ye TZ, Straughen, J, Lennon DJ, et al: The Bloom's syndrome gene product is homologous to RecQ helicases. Cell 83: 655-666 (1995).

Fedhila-Ben Ayed F, Douira-Khomsi W, Rhayem $\mathrm{S}$, Jelassi M, Zribi H, et al: Burkitt lymphoma in a child with Bloom syndrome. Arch Pediatr 23:382-384 (2016).

Flanagan M, Cunniff CM: Bloom syndrome, in Adam MP, Ardinger HH, Pagon RA, Wallace SE, Bean LJH, et al (eds): GeneReview ${ }^{\circledR}$ [Internet] (University of Washington, Seattle 1993-2020). Initial posting: March 22, 2006; last update: Feb 14, 2019. 
Foretová L, Petráková K: Hereditární nádorová onemocnění V. Klin Onkol 32(Suppl) (2019).

German J: Bloom's syndrome. I. Genetical and clinical observations in the first twenty-seven patients. Am J Hum Genet 21:196-227 (1969).

German J, Sanz MM, Ciocci S, Ye TZ, Ellis NA: Syndrome-causing mutations of the BLM gene in persons in the Bloom's Syndrome Registry. Hum Mut 28:743-753 (2007).

Gretzula JC, Hevia O, Weber PJ: Bloom's syndrome. J Am Acad Dermatol 17:479-488 (1987).

Jastaniah W: Successful treatment of mature Bcell lymphoma with rituximab-based chemotherapy in a patient with Bloom syndrome. Pediatr Blood Cancer 64 (2017).

Karow JK, Chakraverty RK, Hickson ID: The Bloom's syndrome gene product is a $3^{\prime}-5^{\prime}$ DNA helicase. J Biol Chem 272:30611-30614 (1997).

Kaseb H, Hozayen S: Chromosome Instability Syndromes, in StatPearls [Internet] Treasure Island (FL): StatPearls Publishing (2019).
Kleinberger J, Maloney KA, Pollin TI, Jeng LJ: An openly available online tool for implementing the ACMG/AMP standards and guidelines for the interpretation of sequence variants. Genet Med 18:1165 (2016).

Masmoudi A, Marrakchi S, Kamoun H, Chaaben H, Ben Salah G, et al: Clinical and laboratory findings in 8 patients with Bloom's syndrome. J Dermatol Case Rep 6:29-33 (2012).

McGowan J, Maize J, Cook J: Lupus-like histopathology in Bloom syndrome: reexamining the clinical and histologic implications of photosensitivity. Am J Dermatopathol 31:786-791 (2009).

Nair G, Lobo I, Jayalaksmi TK, Uppe A, Jindal S, et al: Bloom syndrome with lung involvement. Lung India 26:92-94 (2009).

Prokofyeva D, Bogdanova N, Dubrowinskaja N, Bermisheva M, Takhirova Z, et al: Nonsense mutation p.Q548X in BLM, the gene mutated in Bloom's syndrome, is associated with breast cancer in Slavic populations. Breast Cancer Res Treat 137:533-539 (2013)

Relhan V, Sinhan S, Bhatnagar T, Garg VK, Kochhar A: Bloom syndrome with extensive pulmonary involvement in a child. Indian J Dermatol 60:217 (2015)
Richards S, Aziz N, Bale S, Bick D, Das S, GastierFoster J, et al: Standards and guidelines for the interpretation of sequence variants: a joint consensus recommendation of the American College of Medical Genetics and Genomics and the Association for Molecular Pathology. Genet Med 17:405-424 (2015).

Seemanová E, Seeman P, Jarolím P: Význam syndromů chromozomální instability. Čas Lék Čes 141:16-22 (2002).

Shahrabani-Gargir L, Shomrat R, Yaron Y, OrrUrtreger A, Groden J, Legum C: High frequency of a common Bloom syndrome Ashkenazi mutation among Jews of Polish origin. Genet Test 2:293-296 (1998).

Sokolenko AP, Iyevleva AG, Preobrazhenskaya EV, Mitiushkina NV, Abysheva SN, et al: High prevalence and breast cancer predisposing role of the BLM c.1642C>T (Q548X) mutation in Russia. Int J Cancer 130:2867-2873 (2012).

Swerdlow SH, Campo E, Pileri SA, Harris NL, Stein H, et al: The 2016 revision of the World Health Organization classification of lymphoid neoplasms. Blood 127:2375-2390 (2016). 